\title{
EFFECTIVENESS OF HEALTH EDUCATION FAMILY PLANNING GUIDELINES ON HEALTH BELIEFS AND BEHAVIOURS REGARDING FAMILY PLANNING METHODS AMONG MARRIED MEN IN MYANMAR
}

\author{
Zay Yar Tun*, Tintin Sukartini** \\ * Military Institute of Nursing and Paramedical Sciences, Myanmar \\ ** Faculty of Nursing Universitas Airlangga, Kampus C Mulyorejo Surabaya, 60115 \\ Email: zayyarprince@gmail.com
}

\begin{abstract}
Introduction: Males are the most important members and care-takers of the family, but they are considered to be uncooperative when it comes to the usage of family planning methods. Traditionally, family planning programs have focused primarily on women, and most of the methods are designed for women considering that it is the women who become pregnant and it is easy to deliver reproductive health services as part of maternal and child health programs. The main objective of this study was to study the effectiveness of Health Education (HE) Family Planning Guidelines on Health Belief and Behaviours regarding family planning methods among married men Methods: A quasi-experimental study design was used to compare the results of the effectiveness of health education on the health beliefs and behaviours regarding family planning methods among married men. Mann-Whitney test and Manova test were used to analyse the data. Results: It was found that there was a difference of health belief with $\mathrm{p}=0.038$, knowledge with $\mathrm{p}=0.000$ and attitude with $\mathrm{p}=0.000$ between the treatment and control group. Conclusions: There was an impact on the improvement of health belief and behaviours regarding family planning methods in the study group which was significantly improved after intervention. As the predetermined hypothesis, a difference was found between the knowledge, attitude and health beliefs of the married men who received health education and those who did not receive health education.
\end{abstract}

Keywords: behaviours, family planning, health belief, married men

\section{INTRODUCTION}

Family planning is a way of thinking and living that is adopted voluntarily on the basis of knowledge, attitude and responsible decisions by individuals and couples in order to promote health and welfare of the family, groups and thus to contribute effectively to the social development of the country (WHO, 2011). Males are the most important members and caretakers of the family, but they are considered to be uncooperative when it comes to the usage of family planning methods. Traditionally, family planning programs have focused primarily on women, and most of the methods are designed for women considering that it is the women who become pregnant and it is easy to deliver reproductive health services as part of maternal and child health programs (Adelekan et al., 2014). Despite global recognition of the importance of male involvement in family planning, Myanmar has not developed a program in family planning that fully involves men. Most family planning programs in our environment seem to focus on women only. The non-inclusion of men in various family planning programs by the program planners has made men not know much about family planning and the benefits to their spouses and family, especially in rural communities. Yet men can participate in family planning either as the users of male methods or as supportive partners of users (Fumilayo and Kolawole, 2000, Chinma, 2014). Men have rarely been involved in either receiving or providing information on sexuality, reproductive health, or birth spacing. They have also been ignored or excluded in one way or another from participating in many FP programs as FP is viewed as a woman's affair (Walle et al., 2014).

In the global society, 1,600 women and more than 10,000 newborns die from preventable complications during pregnancy and childbirth every day. Almost $99 \%$ of the maternal and $90 \%$ of the neonatal deaths occur in developing countries. As the first pillar of safe motherhood and as an essential component of primary health care, family planning plays a major role in reducing maternal and newborn morbidity and mortality (WHO, 2012). The maternal mortality ratio in developing countries in 2015 was 239 per 100000 live births versus 12 per 100000 live births in developed countries. There are large disparities between countries, but also within countries, between women with high and low income, and women living in rural versus urban areas (WHO, 2015). Rapid population growth represents one of the major population concerns in Myanmar where the population 
growth rate is $1.0 \%$, and this is estimated to exceed 58.6 million in 2050. In 2014, the population of Myanmar was about 51 million people. The sex ratio of the total population is 0.93 comprising of 93 males per 100 females (MOH, 2014). Family planning plays one of the more important roles in controlling the population growth rate of the country. In general, the consequences of a lack of access to FP are not only a high number of undesired pregnancies but also the increased risk of sexually transmitted diseases and a high number of abortions (WHO, 2014). The unmet needs for FP in Myanmar stand at 19\%, compared with only 3\% in neighbouring Thailand (MIO, 2014). A total of $70 \%$ of the population live in rural areas with little or no access to FP and maternal health services (MIO, 2014). Maternal mortality in Myanmar is 200 per 100,000 live births (DOP, 2014).

The United Nations Population Fund reports that $87 \%$ of maternal deaths occur in rural areas, largely due to poor infrastructure and a lack of reproductive health access and awareness (World Bank, 2013). The reduction of unintended pregnancies can also result in fewer abortions, which can carry a high mortality risk when there are complications (Siri \& Munsawaengsub, 2016). It is now increasingly recognised that the actions required to achieve improvements in family planning should also encourage the active participation of men (Rekha et al., 2015). The Myanmar Ministry of Health reports the contraceptive use of the whole country at $46 \%$ and hopes to increase this to $50 \%(\mathrm{MOH}$, 2012). In Wundwin Township, the total population is 235000 . Among them, the total birth population is 3500 , stillbirths are 50 , abortions are 80 , and maternal deaths were 5 in 2015. According to the 2015 report of Lay Myat Nar and Pin Ta Lae rural health centres (RHC), the total live-births is 100 per 5158 population. Among them, there were included 4 still-births, 15 abortion cases and 2 maternal deaths.

Based on the description in the background of the formulation of the problem, the researcher will determine the knowledge and attitude regarding family planning methods among married men who live in Lay Myat Nar village, Pin Ta Lae village in the Mandalay Region in Myanmar based on the health belief model.

\section{MATERIALS AND METHODS}

The study design was a forum to answer the research questions or to test the hypothesis expertise (Nursalam, 2008). In this study, a quasi-experimental study design was used to compare the results of the effectiveness of health education on health belief and behaviours regarding family planning methods among married men. Each group had 45 married men in whose wives were still of female reproductive age. This study was conducted at Pin Ta Lae and Lay Myat Nar villages, in the Wundwin Township of the Mandalay Region in Myanmar. The data was collected from the sample population by conducting face to face interviews using a structured interview questionnaire. A MannWhitney test and an ANOVA test was used to analyse the data. Approval and permission to conduct the study were given by the Research Ethics Committee of the Military Institute of Nursing and Paramedical Sciences, Myanmar, and a recommendation for the protection of human rights and welfare in medical research came from the ethical committee of the Faculty of Nursing, of the Universitas Airlangga in Surabaya, Indonesia. The approval and permission to conduct this study were obtained from the Department of Medical Science, in the Department of Health, of the Ministry of Health of Nay Pyi Taw, Myanmar.

\section{RESULTS}

Table 1 shows that the characteristics of the respondents in the intervention group based the respondent's age which was between 36-45 years for as many as 20 respondents (44.4\%). Characteristics of all of the respondents of the Buddhist religion were as many as 45 respondents (100\%). The most popular education level of the respondents was primary school level that was 16 respondents $(35.6 \%)$. Characteristics based on the occupation of the respondents was that of a farmer, which was 31 respondents (68.9\%). The characteristics of the respondents based on the total family income were 1 lakh and under for as many as 27 of the respondents $(60.0 \%)$. Most of the respondents had children; 37 respondents (82.2\%).In the control group, it showed that the characteristics of the respondents in the control group based on the respondent's age 
Table 1 Distribution of respondents based on the characteristics of respondents in the treatment group and control group

\begin{tabular}{|c|c|c|c|c|}
\hline \multirow[t]{2}{*}{ Characteristics } & \multicolumn{2}{|c|}{$\begin{array}{l}\text { Intervention } \\
\text { Group }\end{array}$} & \multicolumn{2}{|c|}{$\begin{array}{l}\text { Control } \\
\text { Group }\end{array}$} \\
\hline & $\mathrm{f}$ & $\%$ & $\mathrm{f}$ & $\%$ \\
\hline \multicolumn{5}{|l|}{ Age } \\
\hline$<25$ years & 4 & 8.9 & 4 & 8.9 \\
\hline $26-35$ years & 9 & 20.0 & 17 & 37.8 \\
\hline $36-45$ years & 20 & 44.4 & 18 & 40.0 \\
\hline $46-55$ years & 12 & 26.7 & 4 & 8.9 \\
\hline 56 or older & & & 2 & 4.4 \\
\hline \multicolumn{5}{|l|}{ Religion } \\
\hline Buddish & 45 & 100 & 45 & 100 \\
\hline \multicolumn{5}{|l|}{ Education } \\
\hline Illiterate & & & 2 & 4.4 \\
\hline Can read \& write & 2 & 4.4 & 4 & 8.9 \\
\hline Primary school level & 16 & 35.6 & 8 & 17.8 \\
\hline Middle school level & 15 & 33.3 & 13 & 28.9 \\
\hline High school level & 12 & 26.7 & 18 & 40.0 \\
\hline \multicolumn{5}{|l|}{ Occupation } \\
\hline Farmer & 31 & 68.9 & 20 & 44.4 \\
\hline Government employee & 1 & 2.2 & 5 & 11.1 \\
\hline Merchant & 3 & 6.7 & 5 & 11.1 \\
\hline Private employee & 2 & 4.4 & 2 & 4.4 \\
\hline Daily labourer & 8 & 17.8 & 13 & 28.9 \\
\hline \multicolumn{5}{|l|}{ Total Family income } \\
\hline 1 lakh and under & 27 & 60.0 & 27 & 60.0 \\
\hline 100001 to 200000 & 13 & 28.9 & 15 & 33.3 \\
\hline 200001 to 300000 & 5 & 11.1 & 2 & 4.4 \\
\hline More than 300000 & & & 1 & 2.2 \\
\hline \multicolumn{5}{|l|}{ Having Child } \\
\hline No & 8 & 17.8 & 12 & 26.7 \\
\hline Yes & 37 & 82.2 & 33 & 73.3 \\
\hline \multicolumn{5}{|l|}{ Child Number } \\
\hline 0 & 8 & 17.8 & 12 & 26.7 \\
\hline 1 & 9 & 20 & 10 & 22.2 \\
\hline 2 & 13 & 28.4 & 11 & 24.4 \\
\hline 3 & 11 & 24.4 & 7 & 5.6 \\
\hline 4 & 3 & 6.7 & 2 & 4.4 \\
\hline 5 & 1 & 2.2 & 2 & 4.4 \\
\hline 6 & & & 1 & 2.2 \\
\hline \multicolumn{5}{|l|}{ Age } \\
\hline 1 & 10 & 22.2 & 21 & 46.7 \\
\hline 2 & 15 & 33.3 & 19 & 42.2 \\
\hline 3 & 20 & 44.4 & 5 & 11.1 \\
\hline
\end{tabular}

was that those aged between $36-45$ years was 18 of the respondents $(40 \%)$. The characteristics of all of the respondents were of the Buddhist religion; 45 respondents $(100 \%)$. The education level of the respondents who went to high school was 18 respondents $(40 \%)$. The characteristic based on the occupation of the respondent was that of a farmer; 20 respondents (44.4\%). The characteristic of the respondents based on the total family income was 1 lakh and under as the most frequent; 27 respondents $(60.0 \%)$.
Most of the respondents have children; 33 respondents $(73.3 \%)$.

Table 2 shows that the knowledge of the respondents in the intervention group in the pre-test was that 18 respondents $(40 \%)$ were in the poor category, 26 respondents $(57.78 \%)$ were in enough category and 1 respondent $(2.22 \%)$ was in a good category. In the post-test, there were 24 respondents $(53.33 \%)$ in enough category and 21 respondents $(46.67 \%)$ in the good category. In the control group, there were 21 respondents $(46.67 \%)$ in the poor category, 20 respondents $(44.44 \%)$ in enough category and 4 respondents $(8.89 \%)$ in the good category. There were 31 respondents $(68.89 \%)$ in the poor category, 12 respondents $(26.67 \%)$ in enough category and 2 respondents $(4.44 \%)$ in the good category in the post-test.

Table 3 shows that the attitude of the respondents in the intervention group in the pre-test was 40 respondents $(88.89 \%)$ had a positive attitude and 5 respondents $(11.11 \%)$ had a negative attitude. In the post-test, all of the respondents $(100 \%)$ had a positive attitude. In the pre-test of the control group, there were 39 respondents $(86.67 \%)$ that had a positive attitude and 6 respondents $(13.33 \%)$ that had a negative attitude. In the post-test, there were 38 respondents $(84.44 \%)$ that had a positive

Table 2. Distribution of Knowledge (pre and post-test)

\begin{tabular}{cccccc}
\hline \multirow{2}{*}{ Knowledge } & \multicolumn{4}{c}{ Group } \\
\cline { 2 - 6 } & & \multicolumn{2}{c}{ Intervention } & \multicolumn{2}{c}{ Control } \\
\cline { 2 - 6 } & $\mathbf{f}$ & $\mathbf{\%}$ & $\mathbf{f}$ & $\mathbf{\%}$ \\
\hline \multirow{3}{*}{$\begin{array}{c}\text { Pre } \\
\text { test }\end{array}$} & Poor & 18 & 40 & 21 & 46.67 \\
\cline { 2 - 6 } & Enough & 26 & 57.78 & 20 & 44.44 \\
\cline { 2 - 6 } & Good & 1 & 2.22 & 4 & 8.89 \\
\cline { 2 - 6 } & Total & 45 & 100 & 45 & 100 \\
\hline \multirow{3}{*}{$\begin{array}{c}\text { Post } \\
\text { test }\end{array}$} & Poor & - & & 31 & 68.89 \\
\cline { 2 - 6 } & Enough & 24 & 53.33 & 12 & 26.67 \\
\cline { 2 - 6 } & Good & 21 & 46.67 & 2 & 4.44 \\
\cline { 2 - 6 } & Total & 45 & 100 & 45 & 100 \\
\hline
\end{tabular}

Table 3. Distribution of Attitude (pre and post-test)

\begin{tabular}{cccccc}
\hline \multirow{2}{*}{ Attitude } & \multicolumn{4}{c}{ Group } \\
\cline { 3 - 6 } & & \multicolumn{2}{c}{ Intervention } & \multicolumn{2}{c}{ Control } \\
\cline { 2 - 6 } & $\mathbf{f}$ & $\mathbf{\%}$ & $\mathbf{f}$ & $\%$ \\
\hline Pre & Positive & 40 & 88.89 & 39 & 86.67 \\
\cline { 2 - 6 } test & Negative & 5 & 11.11 & 6 & 13.33 \\
\hline Post & Positive & 45 & 100 & 38 & 84.44 \\
\cline { 2 - 6 } test & Negative & - & - & 7 & 15.56 \\
\hline
\end{tabular}


Effectiveness of Health Education Family Planning Guidelines... (Zay Yar Tun, Tintin Sukartini)

Table 4. Distribution of Health Belief Scores (pre and post-test)

\begin{tabular}{|c|c|c|c|c|c|c|}
\hline \multirow[t]{3}{*}{ Variable } & & \multirow[t]{3}{*}{ Category } & \multicolumn{4}{|c|}{ Group } \\
\hline & & & \multicolumn{2}{|c|}{ Intervention } & \multicolumn{2}{|c|}{ Control } \\
\hline & & & Amount & $\%$ & Amount & $\%$ \\
\hline \multirow{8}{*}{$\begin{array}{c}\text { Perceived } \\
\text { susceptibility }\end{array}$} & \multirow{4}{*}{ Pre test } & Poor & - & & - & \\
\hline & & Enough & 3 & $6.67 \%$ & 8 & $17.78 \%$ \\
\hline & & Good & 37 & $82.82 \%$ & 28 & $62.22 \%$ \\
\hline & & Very good & 5 & $11.11 \%$ & 9 & $20 \%$ \\
\hline & \multirow{4}{*}{ Post test } & Poor & - & - & - & - \\
\hline & & Enough & - & - & 8 & $17.78 \%$ \\
\hline & & Good & 36 & $80 \%$ & 31 & $68.89 \%$ \\
\hline & & Very good & 9 & $20 \%$ & 6 & $13.33 \%$ \\
\hline \multirow{8}{*}{$\begin{array}{l}\text { Perceived } \\
\text { Severity }\end{array}$} & \multirow{4}{*}{ Pre test } & Poor & - & - & - & - \\
\hline & & Enough & 4 & $8.89 \%$ & 2 & $4.44 \%$ \\
\hline & & Good & 27 & $60 \%$ & 28 & $62.22 \%$ \\
\hline & & Very good & 14 & $31.11 \%$ & 15 & $33.33 \%$ \\
\hline & \multirow{4}{*}{ Post test } & Poor & - & - & - & - \\
\hline & & Enough & - & - & 1 & $2.22 \%$ \\
\hline & & Good & 14 & $31.11 \%$ & 18 & $40 \%$ \\
\hline & & Very good & 31 & $68.89 \%$ & 26 & $57.78 \%$ \\
\hline \multirow{8}{*}{$\begin{array}{l}\text { Perceived } \\
\text { benefit }\end{array}$} & \multirow{4}{*}{ Pre test } & Poor & - & - & - & - \\
\hline & & Enough & 2 & $4.44 \%$ & - & - \\
\hline & & Good & 20 & $44.44 \%$ & 31 & $68.89 \%$ \\
\hline & & Very good & 23 & $51.11 \%$ & 14 & $31.11 \%$ \\
\hline & \multirow{4}{*}{ Post test } & Poor & - & - & - & - \\
\hline & & Enough & - & - & 7 & $15.56 \%$ \\
\hline & & Good & 14 & $31.11 \%$ & 33 & $73.33 \%$ \\
\hline & & Very good & 31 & $68.89 \%$ & 5 & $11.11 \%$ \\
\hline \multirow{8}{*}{$\begin{array}{l}\text { Perceived } \\
\text { barrier }\end{array}$} & \multirow{4}{*}{ Pre test } & Poor & - & - & - & - \\
\hline & & Enough & 1 & $2.22 \%$ & 3 & $6.67 \%$ \\
\hline & & Good & 38 & $84.44 \%$ & 36 & $80 \%$ \\
\hline & & Very good & 6 & $13.33 \%$ & 6 & $13.33 \%$ \\
\hline & \multirow{4}{*}{ Post test } & Poor & - & - & - & - \\
\hline & & Enough & 1 & $2.22 \%$ & 3 & $6.67 \%$ \\
\hline & & Good & 18 & $40 \%$ & 39 & $86.67 \%$ \\
\hline & & Very good & 26 & $57.78 \%$ & 3 & $6.67 \%$ \\
\hline \multirow{8}{*}{ Self-efficacy } & \multirow{4}{*}{ Pre test } & Poor & - & - & - & - \\
\hline & & Enough & 2 & $4.44 \%$ & 5 & $11.11 \%$ \\
\hline & & Good & 29 & $64.44 \%$ & 28 & $62.22 \%$ \\
\hline & & Very good & 14 & $31.11 \%$ & 12 & $26.67 \%$ \\
\hline & \multirow{4}{*}{ Post test } & Poor & - & - & - & - \\
\hline & & Enough & - & - & 4 & $8.89 \%$ \\
\hline & & Good & 17 & $37.78 \%$ & 34 & $75.56 \%$ \\
\hline & & Very good & 28 & $62.22 \%$ & 7 & $15.56 \%$ \\
\hline
\end{tabular}

attitude and 7 respondents $(15.56 \%)$ that had a negative attitude.

Table 4 shows that the majority of the respondents to do with perceived susceptibility in the intervention group in pre-test were in a good category, and only three respondents were in enough category. In the post-test, 9 respondents $(20 \%)$ increased into the very good category. In the control group of the pretest, the majority of the respondents were in a good category, and 8 respondents $(20 \%)$ were in enough category. In the post-test, three respondents were decreased from the very good category into the good category. The majority of the respondents in relation to the perceived severity in the intervention group in the pre-test were in a good category, and only 4 respondents were in enough category. In the post-test, 17 respondents were increased into the very good category. In the control group of the pre-test, the majority of the respondents were in a good category, and only 2 respondents were in enough category. In the post-test, 11 respondents were increased into the very good category.

The majority of respondents in relation to the perceived benefit of the respondents in the intervention group in the pre-test were in the very good category, and only 2 respondents were in enough category. In the 
_Table 5 The results of Mann Whitney test

\begin{tabular}{lll}
\multicolumn{1}{c}{ Variables } & Sig. \\
\hline Knowledge & Post Intervention and Post Control & .000 \\
\hline Attitude & Post Intervention and Post Control & .000 \\
\hline Perceived Susceptibility & Post Intervention and Post Control & .000 \\
\hline Perceived Severity & Post Intervention and Post Control & .000 \\
\hline Perceived Benefit & Post Intervention and Post Control & .000 \\
\hline Perceived Barrier & Post Intervention and Post Control & .000 \\
\hline Self-Efficacy & Post Intervention and Post Control & .000 \\
\hline
\end{tabular}

Table 6 Test the difference between the treatment group and the control group by using Manova test

\begin{tabular}{clcccc}
\hline Effect & & Value & F & Hypothesis df & Sig \\
\hline$H E$ & Pillai's trace & .661 & $55.962^{\mathrm{b}}$ & 3.000 & .000 \\
\hline Wilk's lambda & .339 & $55.962^{\mathrm{b}}$ & 3.000 & .000 \\
\hline Hotteling's trace & 1.952 & $55.962^{\mathrm{b}}$ & 3.000 & .000 \\
\hline Roy's largest root & 1.952 & $55.962^{\mathrm{b}}$ & 3.000 & .000 \\
\hline
\end{tabular}

Tabel 7 The results of the analysis on the intervention group and the control group by using Manova Test

\begin{tabular}{|c|c|c|c|c|}
\hline Variables & df & Mean & $\mathbf{F}$ & P value \\
\hline Knowledge & 1 & 852.544 & 124.726 & .000 \\
\hline Attitude & 1 & 915.211 & 37.500 & .000 \\
\hline Health Belief & 1 & 3397.878 & 52.294 & .000 \\
\hline Perceived Susceptibility & 1 & 122.500 & 22.777 & .000 \\
\hline Perceived Severity & 1 & 30.044 & 5.961 & .017 \\
\hline Perceived Benefit & 1 & 380.278 & 51.103 & .000 \\
\hline Perceived Barrier & 1 & 313.600 & 60.402 & .000 \\
\hline Self-Efficacy & 1 & 74.711 & 15.816 & .000 \\
\hline
\end{tabular}

post-test, 8 respondents were increased into the very good category. In the control group of the pre-test, the majority of the respondents were in a good category. In the post-test, 7 respondents were decreased into enough category. The majority of the respondents in the perceived barrier of respondents in the intervention group in the pre-test were in a good category, and only one respondent was in enough category. In the post-test, 20 respondents were increased into the very good category, and one respondent was still in enough category. In the control group of the pre-test, the majority of the respondents were in a good category, and only 3 respondents were in enough category. In the post-test, 3 respondents were decreased from the very good category into the good category.

Table 5 shows that based on the Mann Whitney test, significant $p<0.05$ for all of the variables and sub-variables. There were differences between the intervention and control group. Health education is effective on health belief.

Table 6 shows that in general, there were differences in average knowledge, attitude and health belief between the intervention and control groups. The results show that the value of Hotteling's trace was sig. 0.000 which means that is smaller than $\alpha$
0.05 . It is stated that there was a difference in knowledge, attitude and health belief between the intervention group and control group.

Table 7 shows that there was a difference in knowledge with $\mathrm{p}=0.000$ and attitude with $\mathrm{p}=0.000$, health belief with $\mathrm{p}=$ 0.000 , perceived susceptibility with $\mathrm{p}=0.000$, perceived severity with $\mathrm{p}=0.017$, perceived benefit with $\mathrm{p}=0.000$, perceived barrier with $\mathrm{p}=0.000$ and self-efficacy with $\mathrm{p}=0.000$ between the intervention group and control group.

\section{DISCUSSION}

To my knowledge, this is the first study conducted in analysing the effect of health education family planning guidelines on health belief and behaviours regarding family planning methods among married men in Myanmar. In this study, the majority of the intervention group have enough knowledge about family planning methods before they had any health education. After giving health education about family planning guidelines, 21 respondents were increased into the good knowledge category. In the control group, there were 21 respondents in the poor category, 20 respondents in enough category and 4 respondents in the good category in the 
pre-test and 31 respondents in the poor category, 12 respondents in enough category and 2 respondents in the good category in the post-test. In this study, most of the respondents had knowledge about contraceptive methods from their friends. Some respondents knew from their health care provider and their wives.

A similar study conducted by Chaudhary et al. (2015) showed that $19.1 \%$ of married men had good knowledge about family planning methods while the majority of men $(58.4 \%)$ had average knowledge. Others $(22.5 \%)$ had poor knowledge about the same. Berhane et al. (2011) revealed that most of the male respondents had information about family planning. About $36.6 \%$ of the respondents knew more than one method of family planning. Nanji et al. (2015) stated that knowledge of family planning from the urban respondents was higher than from the rural respondents. Family planning education could increase the knowledge of men about modern contraceptives, but the use of contraceptives by men may not increase which indicates that the behaviour change process may take a longer time to have an effect (Shahamfar et al., 2007). Mahamed (2012) stated that educational method is effective in increasing the knowledge and improving the attitude of family planning. The use of family planning methods depends on the person's knowledge of the different family planning methods available and the willingness of both spouses to participate in the family planning program. In order to determine the interest of the participants in the subject of family planning, the study sought to establish the participants' general knowledge about the various family planning methods they were familiar and regularly used (Sossou, 2008).

In this study, most of the respondents had a primary and middle-high school level of education. One-third of the respondents had poor knowledge level. The increased knowledge of the respondents in the intervention group may be influenced by factors such as educational level, age and previous information on family planning guidelines. As a result, health education was required to improve the knowledge about family planning methods among married men. Health education about family planning guidelines can also increase the score of knowledge in the treatment group. In this study, the researcher gave health education about family planning guidelines by group teaching methods by using booklets and a computer as a visual aid. The researcher assumed that the increase of the knowledge score could be caused by providing health education with group teaching methods.

The majority of the respondents of the intervention group had a positive attitude, and five respondents had a negative attitude before the intervention. After the intervention, all of the respondents increased into having a positive attitude. In the control group, the majority of the respondents had a positive attitude, and six respondents had a negative attitude. In the post-test of the control group, the majority of the respondents had a positive attitude, and seven respondents had a negative attitude.

Khamis (2007) stated that most of the husbands $(89.3 \%)$ had positive attitudes towards family planning and agreed that modern methods are more effective than traditional methods. Chaudhary et al. (2015) showed that only $(10 \%)$ of married men had a positive attitude towards family planning while the majority (64.4\%) had an average attitude. $(25.6 \%)$ men had a negative attitude towards the same. Ayub et al. (2015) revealed that most of the respondents had a positive attitude towards family planning and appreciated the effectiveness of modern methods over traditional methods. Mahamed (2012) stated that there was a significant improvement in the respondents' attitude after undergoing the educational program in the experimental group. Bani et al. (2014) revealed that more than half of the men $(52.8 \%)$ had good knowledge about the family planning program. However, most men (84.1\%) had a positive attitude regarding family planning programs, and also they had $(66.6 \%)$ an increased rate of participation. It will be noteworthy that attitude is a response that comes from knowledge and experience. Attitude consists of three elements; cognitive, affective and behavioural. An affective domain is related to bad or good, negative or positive, helpful or not helpful feelings in every individual. The behavioural aspect is the individual's readiness for action.

In this study, most of the respondents had a positive attitude about family planning. It may be that they have proper knowledge about family planning methods. However, 
their information about family planning can still be inadequate. They do not know the different family planning methods, and how and where they are inserted. In addition, they do not know the side effects of the different family planning methods. In this study, the researcher mentioned the benefits of family planning and the advantages and side effects of the male contraceptive methods to improve the attitude level and to decrease the misconceptions about married men. Group teaching methods using booklets and a laptop was effective in improving the attitude level of married men. The men's attitude was much more important in the adaptation of family planning methods. Men should have a good attitude level about family planning.

The majority of the respondents in the intervention group in relation to perceived susceptibility had a good score before the intervention, and nine respondents were increased into the very good score after the intervention. In the control group, the majority of the respondents in perceived susceptibility had a good score both pre- and post-test. The majority of the respondents of the intervention group in perceived severity had a good score before the intervention, and 17 respondents were increased into the very good score after the intervention. In the control group, the majority of the respondents in perceived severity had a good score in both the pre- and post-test.

The majority of the respondents in the intervention group in perceived benefit had a very good score before the intervention, and eight respondents were increased into the very good score category after the intervention. In the control group, the majority of the respondents in perceived benefit had a good score both pre- and post-test. The majority of the respondents in the intervention group in perceived barrier had a good score before the intervention, and the majority of respondents had a very good score after the intervention. In the control group, the majority of the respondents in perceived barrier had a good score in both pre- and post-test. The majority of the respondents in the intervention group in self-efficacy had a good score before the intervention, and majority of the respondents were increased to a very good score after the intervention. In the control group, the majority of the respondents in self-efficacy had a good score both pre- and post-test.
Mahmoodi et al. (2011) stated that there was a significant difference between before and after education. The result of the paired T-test between the before and after scores of perceived threat, perceived benefits and perceived barriers reveals that education improves the individuals' perceptions about participation in family planning programs. In this study, married men from both groups had a good level of health belief, and the post-test score of the intervention group was increased significantly. In this study, the researcher gave a health education program by using group teaching methods among married men. When giving the health education, the intervention group was divided into three groups, and each group involved 15 respondents. The researcher used booklets and a laptop as visual aids for a more effective learning process. The researcher assumed that the increase in the health belief score could be caused by offering health education with group teaching methods.

\section{CONCLUSION}

Health education family planning guidelines significantly affect health belief and behaviours regarding family planning methods among married men in Myanmar. This study can be used as a preliminary study to identify the effectiveness of health education family planning guidelines on health belief and behaviours regarding family planning methods among married men. Men are encouraged to participate in family planning programs, and the appropriate centres and departments should promote health education family planning guidelines for men to improve their knowledge.

\section{REFERENCES}

Adelekan, A., Omoregie, P. \& Edoni, E., 2014. Male Involvement in Family Planning: Challenges and Way Forward. , 2014.

Ayub, A., Kibria, Z., \& Khan, F., 2015. Assessment of Knowledge, Attitude and Contraceptive use in Married Women of Peshawar, Vol. 9 (1):1-2

Bani, S. Et Al. (2014) 'International Journal of Awareness, Attitude And Participation Rate Of Men In Family Planning Programs In Iran', 2(1).

Berhane, A., Biadgilign, S., Amberbir, A., Morankar, S., Berhane, A., \& Deribe, 
K. (2011). Men ' s Knowledge and Spousal Communication about Modern Family Planning Methods in Ethiopia, 15(December), 24-32.

Chaudhary, B. K., Wantamutte, A. S., \& Sah, J. K. (2015). Knowledge, attitude and practices regarding family planning methods among married men in urban field practice area of Ramnagar urban health center , Belagavi- A crosssectional study, 8, 212-219.

Department of Population, Ministry of Immigration and Population. The population and housing census of Myanmar 2014 summary of the provision results. http://country office.unfpa.org/myanmar/drive/Sum mmary of the Provisional Results.pdf. Accessed January 2015.

Fumilayo, O. and Kolawole, K. O. (2000) Training Hand book for family planning clinics, services providers, fertility Research unit, college of medicine University of Ibadan.

Khamis, Y., \& Almualm, A. (2007). Knowledge, attitude and practice of husbands towards modern family planning in Mukalla, Yemin.

Mahamed, F. (2012) 'Impact of Family Planning Health Education on the Knowledge and Attitude among Yasoujian Women', 4(2), pp. 110118. doi: 10.5539/gjhs.v4n2p110.

Mahmoodi, A. et al. (2011) ' The Impact of Education using Health Belief Model on awareness and attitude of male Teachers Regarding Their Participation in Family Planning', (1), pp. 45-49.

Ministry of Immigration and Population. Summary of the provisional result 2014. http://unstats.un.org/unsd/ demographic/sources/census/2010_ PHC/Myanmar/MMR-2015-05.pdf. Accessed July 2014.

Ministry of Health. Health in Myanmar, 2013. Naypyidaw, Myanmar: Ministry of Health; 2014.

Ministry of Health. Township health report. Naypyidaw, Myanmar: Township Health Department, Aung Lan Township; 2012.

Nnaji, G. A., Eze, P. N., Ugwoke, U. M., \& Ifeadike, C. O. (2015). Comparative assessment of family planning knowledge and attitude of men in urban and rural areas of Anambra state , South-East of Nigeria, 2. http://doi.org/10.7243/2054-9865-2-3

Nursalam 2008, Concept and Application of Research Methodology of Nursing Science. Thesis and nursing research instrument. Jakarta: Salemba Medika

Rekha, T., Unnikrishnan, B., Mithra, P. P., \& Kumar, N. (2015). Married Men' $s$ Involvement in Family Planning - A Study from Coastal, 9(4), 7-10.

Shahamfar, J., Kishore, J., \& Shokhvash, B. (2007). Effect of educational intervention on male participation in family planning in Iran, alketa(4), 292-299.

Siri, S. \& Munsawaengsub, C., 2016. Family Planning Practice Among Rural Reproductive-Age Married Women in Myanmar. , alketa.

Sossou, M. A. N. S. (2008) 'Attitudes toward and Use of Knowledge about family Planning among Ghanaian Men', 7(2), pp. 109-120. doi: $10.3149 / \mathrm{jmh}$ 0702.109 .

The World Bank. Working for a world free of poverty, unmet need for contraception (\% of married women ages 15-49) facts sheet. http://data.worldbank.org/ indicator/SP.UWT.TFRT.Accessed July 2013.

Walle, Y., \& Alamrew, Z. (2014). The Current States of Male Involvement on Family Planning and Factors Correlated with among Male Factory Workers in Bahir Dar City, 2(5), 188-197. http://doi.org/10.12691/ajphr-2-5-2

WHO, (2011). World Health Organization (2011) Family Planning a Global handbook for Providers. WHO Geneva.

WHO. Addressing the challenges of women's health in Africa. The commission on women's health in Africa report. WHO Africa Office.2012.

WHO (2015). Family Planning. Available at: http://www.who.int/mediacentre/ factsheets/ fs351/en/ [Accessed 9 April 2015].

World Health Organization. Family planning.http://www.who.int/topics/fa mily_planning/en/. Accessed May 2014. 